\title{
Does Commons Grabbing Lead to Resilience Grabbing? The Anti-Politics Machine of Neo-Liberal Agrarian Development and Local Responses
}

\author{
Tobias Haller ${ }^{1, *}$, Fabian Käser ${ }^{1}$ and Mariah Ngutu ${ }^{2}$ \\ 1 Institute of Social Anthropology, University of Bern, Lerchenweg 36, 3000 Bern 9, Switzerland; \\ fabian.kaeser@anthro.unibe.ch \\ 2 Institute of Anthropology, Gender \& African Studies, University of Nairobi, P.O. Box 30197-00100, Nairobi, \\ Kenya; mariahngutu@gmail.com \\ * Correspondence: tobias.haller@anthro.unibe.ch
}

Received: 27 May 2020; Accepted: 29 June 2020; Published: 8 July 2020

check for updates

\section{Introduction}

This Special Issue contributes to the debate that land grabbing should be discussed as commons grabbing. But it also goes a step further. It poses this question: does commons grabbing also removes local people's capacity for resilience in the Global South, especially in Africa and if so how does that process unfold? The contributions share a focus on how the development of state institutions (formal laws and regulations for agrarian development and compensation) and voluntary corporate social responsibility (CSR) initiatives by investors have enabled the grabbing process of not just removing land but land and land-related common-pool resources formally previously governed by local common property institutions. The papers look at how state institutions (specifically state property of resources and their subsequent privatization) and CSR programs are used for development strategies by state actors and companies to legitimate their investments (Anseeuw et al 2012 [1], Lavers 2012 [2], Schoeneveld and Zoomers 2015 [3]).

Furthermore, the contributions in this Special Issue analyze the embedding of these strategies into neoliberal ideology of economic development (Escobar 1995 [4], Haller 2013 [5]). This ideology defines development as an economic progress of individual efforts adapted to the market to eradicate poverty and promote individual development. Such a view negates processes of power asymmetries and calls for remedies that are often externally defined. In addition, these remedies are often based on notions of private property and economic achievements with low level but nevertheless existing state interference (see Fletcher 2010 [6]). Therefore, state actors still profit from these policies, often without involving local actors and groups apart from local elites. State actors and investors also promote ideologies of modernity based on discourses of market-oriented economic development including green development based on the Sustainable Development Goals (SDGs) (see Haller et al 2018 [7], Haller et al 2019 [8]).

In order shed more light on these dynamics, this Special Issue proposes to take a fresh look at James Ferguson's Anti-Politics Machines (1994 [9], 2006 [10]) that serves to uncover the hidden power asymmetries of actors and political basis of state-driven development strategies in the age of neoliberalism. The papers therefore analyze development discourses and CSR-policies in agrarian as well as green infrastructure-related investments and how these hide power differences. We argue that the various discourses of development further legitimize the institutional change from common to state and private property of land and land-related common-pool resources (Haller ed 2010 [11]), which is the basis of commons grabbing (Haller 2019 [12], Haller this volume [13]).

Moreover, this collection of papers stresses the fact that investments and neoliberal developments affect not just 'wastelands', but land-related common-pool resources of cultural landscape ecosystems, 
previously governed by common property institutions. In addition, the authors illustrate the way institutional change leads to legal and institutional pluralism, and how companies and local as well as state elites select from this institutional pluralism (a process labelled as institution shopping, see Toulmin 2008 [14], Haller 2016 [15], 2019 [12]) depending on their bargaining power and for their own interest to enable and legitimate the grabbing processes.

As a general conclusion-and in answering the question posed by the title of the Special Issue-the research presented here suggests that investments using institutional pluralism related to development, not only lead to commons grabbing, but also to "resilience grabbing": CSR programs and compensations in the form of financial payments or employment do not cover local people's loss of common-pool resources for subsistence and cash. In particular, women and minorities are often not able to get access to the few jobs available and to compensations, which are often low and unequally distributed (Marfurt et al 2016 [16], Haller et al 2019 [8]). In the cases where women do get access to jobs, these are badly paid, of short duration and compete with other duties of reproductive work (see Ngutu et al, this volume). This means that access to the commons, which enhanced local resilience in times of crisis in the past, is no longer available, while at the same time the promises of work and access to compensation and development programs are not kept by states and investors. As a consequence, marginal local people are under conditions of commons grabbing more vulnerable to environmental disturbances and less resilient than they were before.

Finally, the contributions of this Special Issue also present local perceptions and related responses of commoners to the grabbing-process, go beyond resistance, acquaintance and incorporation (see Hall et al 2015 [17]). They include further strategies ranging from weapons of the weak (Scott 1987 [18]) to options of mobilization (labelled as politics machines, see Niederberger et al 2016 [19]), containing also institution shopping from below (on customary and human rights laws and regulations, see Marfurt 2019 [20]) and bottom-up institution building processes to reclaim the commons and its new participatory governance (see constitutionality approach by Haller, Acciaioli and Rist 2016 [21], Haller, Belsky and Rist 2018 [22]).

The papers of this Special Issue were written by 22 authors from nine university institutes from five countries (Switzerland, Kenya, Cambodia, New Zealand and Bolivia) covering case studies from Kenya, Tanzania, Morocco, Bolivia, Ecuador, Cambodia. The Special issue is organized in the following way: After the first paper serving as theoretical introductory, the following papers are presented under three main topics such as (a) property transformations and resilience, (b) agricultural neoliberal order and notions of green development and (c) green investments and Anti-Politics Machines:

In the introductory paper [13] theoretical reflections are proposed from a social anthropology perspective that uses a combined New Institutional and Political Ecology approach (NIPE). It looks historically at empirical data from research on African floodplains (Haller ed 2010 [11]). The paper shows that pre-colonial notions of land were embedded into local ontologies and epistemologies, in which land included land-related common-pool resources governed by common property institutions in relation to a non-human and spiritual world. This view also integrated reciprocal access arrangements between different groups that contributed to their resilience. This meaning of land was undermined and defragmented during colonial and post-colonial times, changing, the commons into state and also private property. As a result, this process also contributed to multiple forms of resource regulations for several separated sectors for state administration (agriculture, wildlife, fisheries, water, conservation etc.) of previously inclusively managed cultural landscapes. These new different meanings of land related to institutional pluralism are vital to understand how access to land and related resources is organized in today's neoliberal order following the states debt crisis. Therefore, the paper discusses who has the power to select property rights and resource management institutions and how this selection (institution shopping) can be legitimated by multiple discourses. These include several forms of green economic and sustainable development anti-politics machines used by state elites and investors as well as by local elites to justify investments. Importantly, the paper outlines theoretically how commons grabbing leads to resilience grabbing. Finally, this introduction also proposes that all 
local actors should be much more involved in developing coping strategies enhancing resilience based on their knowledge and experience.

These theoretical reflections can be used to help to analyze the institutional issue regarding land and resource management that arise in the other papers in this Special Issue, which are introduced below under three broad topics:

\section{Property Transformations and Resilience}

The first three papers provide examples of changes in property rights over time from common to state and private property of the neoliberal order. Furthermore, they describe institutional pluralism and the effect this had on livelihoods and resilience. Because property rights have changed substantially in the past, less powerful local actors find less options to recover from environmental or other stress factors. Such historical processes indicate that the grabbing of the commons during colonial times and the plurality of rights for more powerful external actors has reduced local peoples' resilience historically and pose challenges for coping strategies:

Edwin Ameso et al [23] show in their paper based on anthropological research data how local Maasai groups in Northern Kenya have lost large amounts of common land and related pastures and wetlands during colonial as well as postcolonial times. As a result, their mobility as an important aspect of their resilience capacity is badly affected. Therefore, they have tried to diversify their strategies in order to cope with these changes and in order to sustain pastoralism. Maasai are currently combining property institutions and trying to promote holistic management of pasture and the watersheds, leading to a better co-management of resources. However, they are still facing challenges in order to regain resilience with regard to climate and market changes.

Sochanny Hak, John MacAndrew and Andreas Neef [24] examine land grabs in Cambodia in indigenous people's areas over the last decade. They argue that because of these indigenous people lost their commons in the name of national economic development. They illustrate this process of commons grabbing by using the example of two indigenous communities indicating how the titling processes have failed to provide indigenous villagers with effective legal mechanisms to counteract the grabbing process. In addition, the dependency on cash crops and to the loss of communal forests has contributed to loss of livelihood resilience that is also based on the low bargaining power of local actors.

The issue of asymmetric bargaining power is also the topic of the paper of Jemaiyo Chabeda-Barthe and Tobias Haller [25] who discuss how the minority of the original hunter-gatherer group of the Ogiek in Kenya has lost large tracts of common property of their cultural landscape since colonial times. After independence they have tried to enhance their resilience by focusing on apiculture in an area called Mau Forest. Under the new wave of neoliberal land reform in the country, the Ogiek have handed out land to other allied ethnic groups such as the Kalenjin to prevent encroachment from other powerful ethnic groups such as the immigrant Kikuyu using private property rights of land and powerful state relations. This case also shows how all actors use strategies of institution shopping but that the way to be able to do this relies on historically developed power relations.

\section{Agricultural Neoliberal Order and Notions of Green Development}

The next three papers deal with the neoliberal order of agro-industrial capitalist systems and conservation schemes, which shape institutional contexts and resilience of local actors.

Mariah Ngutu et al [26] discuss in their contribution how the agro-industrial food system in Laikipia, Kenya represented by an UK-export oriented commercial horticultural company is driven by a neoliberal privatization of land and resource policies, feeding the European demand for vegetables. This process shapes the access to short-term livelihoods options by offering women poorly paid jobs and increasing their workload as this adds to their domestic and subsistence duties. Furthermore, the actors of the agro-industrial food system have more bargaining power than local peasants to select and transform institutionalized access to former common-pool resources. This undermines local food systems such as agro-pastoralism and small holder agriculture vital for local livelihoods and food 
security. Therefore, the livelihood resilience of local actors is undermined, increasing the potential for conflicts across the different food systems.

Horacio Augstburger, Fabian Käser and Stephan Rist [27] introduce a comparative dimension in their paper, in which they study the similarities and differences between the Laikipia area in Kenya (as the previous paper) and the agro-industrial area in Bolivian Lowlands. They analyse the capacity of several locally occurring food systems to enhance sustainable farm-based agroecosystem services and how they affect the sustainable management of common-pool resources. The authors show that in both countries regional and agro-industrial food systems, embedded in a market oriented neoliberal order, are less socio-ecologically sound than local, indigenous and alternative food systems. The former two have negative impacts on agroecosystems, undermining common property and cultural landscapes. They grab the commons and reduce the resilience capacity of the indigenous and alternative systems. Strengthening local, indigenous and alternative food systems and their common property institutions is proposed as a key strategy to promote sustainable farm-based agroecosystems.

Lisa Alvarado [28] illustrates how strategies to support local common property systems is undermined in the context of neoliberal conservation. She outlines that in the Ecuadorian Amazon region of Ecuador, protected areas have been established as a response to the expansion of the agricultural frontier based on the neoliberal rule in the country since 1979. She focuses on the protected area of the Reserva de Producción Faunística Cuyabeno, that was previously managed as commons by local indigenous groups of the Siona. Before the establishment of the conservation area, the arrival of several waves of colonizers had already severely compromised traditional institutions of common property. Resource use limitations by the introduction of the protected areas have been the last of these grabbing attempts. This green grabbing now forces the Siona people to legitimize their existence in the park, if they want to stay in their ancestral territory. They argue against the green grabbing, especially based on the negative impact of tourism in the park and by trying to shop institutions based on their (reconstructed) indigenous identity that is protected by international conventions.

\section{Green investments and Anti-Politics Machines}

The issue of green grabbing, however in another forms, is the focus of the last three papers, illustrating the environmental turn used by powerful actors of states and companies. These investments show classic forms of commons and resilience grabbing but are embedded in strategies of social and ecological corporate responsibility schemes (CSRs), masking the grabbing process and the undermining of the resilience of marginal groups and women.

Gargule Achiba's [29] paper shows a classical conflict of an internationally-celebrated green investment in a wind park in Northern Kenya. It explains the way land is grabbed but legitimized by green energy Anti-Politics Machine. He shows how the implementation of the wind energy project employs the corporate strategies of depoliticizing both land claims and development interventions. This process hides how the private sector engagement in large-scale wind energy infrastructure has created a complex development apparatus ideologically empowered by using the SDGs and Kenya's related Vision 2030. Furthermore, the green energy grabbing of pastoral land and related common-pool resources is hidden by CSR strategies through which dispossession is justified and legitimized.

Another case of commons grabbing in the name of green energy is illustrated in the contribution of Sarah Ryser [30]. She explains how the largest solar energy project in the world financed by a public-private partnership removes common property of a Moroccan Amazigh (Berber) clan, who's members thereby lose access to pastures and animal fodder. The Anti-Politics Machine of green energy, including compensation payments and CSR development, hides the fact that a very low land price was fixed by the state, and further legitimated by the discourse that the land is wasteland. Furthermore, payments did not reach the communities who also did not fully profit from CSR-programmes and simultaneously lost access to the commons. Thus, they became less resilient as their losses were not replaced by the development gains promised. Women, in particular, lost more than men. 
The issue of gender is a particular focus of the paper by Désirée Gmür [31]. She uses data from her research among the ethnic group of the Wahehe farming communities in Kilolo District, Tanzania, who had a common property system regarding land and land-related resources that included resource co-ownership of clan land by women. The investor in this case first tried to get communal land and then later on so-called private land held by men, who sold it and thereby excluded women form access to land, water and other resources. While more common-pool resources were enclosed and were no longer accessible to women, they also lost most of the valuable agricultural land in the valley bottoms used by them for cash crop production. In addition, the grabbing process by the company also reduced access to veld products and to water, leading to the loss of food and cash providing resources on which women depended for their reproductive work. As the traditional rights of women to land has altered, they are more affected by land and commons grabbing than men and have fewer options in trying to defend their former property. The company on the other hand uses a green development discourse to legitimize the selection on environmental legal state institutions and thus the removal of access to the commons.

\section{Conclusions}

These case studies indicate several elements of the links between historical and contemporary commons grabbing processes and how they undermine resilience in food and cash production systems as well as general livelihoods for marginalized, local communities in the Global South. The cases presented in this Special Issue show that "resilience grabbing" is the result of commons grabbing as a process, in which powerful state and corporate actors as well as local elites use institutional and legal pluralism in the age of neoliberalism. This provides them with the option to select, activate and transform rules and regulations and to use always new forms of discourses (conservation, green economy, green investment, CSR-development programs and SDGs) to legitimate their actions. While the promises of development has been criticized by Ferguson almost three decades ago [9], the contemporary examples in this Special Issue show the same mechanisms still exist, albeit sometimes in new forms, but still legitimizing unfavorable outcomes for local actors with less bargaining power. The tragedy of this notion of development is that in this way the capacity to recover from a human or environmentally-induced land and resources crisis is reduced. It is assumed that the COVID-crisis and the related economic and political outcomes on the local level might illustrate this trend.

However, there are cases that show different forms of local reactions and coping strategies that should be studied further. These may range from small actions of resistance to larger legal claims. In addition, local groups may develop new identities that boost their bargaining power and try to use strategies of institution shopping from below or engage in the development of bottom-up institution building (see Haller et al 2016 [16]). We argue that further research, preferably participatory research (see Haller and Zingerli 2020 [32]), should focus on these issues.

We hope to have contributed to an understanding that land grabbing in fact removes the communal rights to own and use not just land but land-related common-pool resources in cultural landscape ecosystems. These are central for local actors to be able to recover from market and climate induced crisis and to enhance biodiversity. Undermining these rights and local institutions will accelerate the global degradation process and further reduce the capacity for local actors to build up resilience in the face of global environmental and development crises. Enhancing common property and the development of institutions from below by all actors might be one solution to this set of problems.

Funding: The papers of this Special Issue were funded by different research organizations. The respective funding information is provided in the respective papers.

Acknowledgments: We are grateful for administrative and technical support provided by the Institute of Social Anthropology and the Centre for Development and Environment (CDE), both University of Bern, Switzerland

Conflicts of Interest: The authors declare no conflict of interest 


\section{References}

1. Anseeuw, W.; Boche, M.; Breu, T.; Giger, M.; Lay, J.; Messerli, P.; Nolte, K. Transnational Land Deals for Agriculture in the Global South: Analytical Report Based on the Land Matrix Database; CDE/CIRAD/GIGA: Bern, Switzerland; Montpellier, Switzerland; Hamburg, Switzerland, 2012; ISBN 978-92-95093-71-3.

2. Lavers, T. 'Land grab' as development strategy? The political economy of agricultural investment in Ethiopia. J. Peasant. Stud. 2012, 39, 105-132. [CrossRef]

3. Schoneveld, G.C.; Zoomers, A. Natural resource privatisation in Sub-Saharan Africa and the challenges for inclusive green growth. Int. Dev. Plan. Rev. 2015, 37, 95-118. [CrossRef]

4. Escobar, A. Encountering Development. The Making and Unmaking of the Third World; Princeton University Press: Princeton, NJ, USA, 1995.

5. Haller, T. The Contested Floodplain: Institutional Change of the Commons in the Kafue Flats, Zambia; Lexington Books: Lexington, Lanham, 2013.

6. Fletcher, R. Neoliberal environmentality: Towards a poststructuralist political ecology of the conservation debate. Conserv. Soc. 2010, 8, 171-181. [CrossRef]

7. Haller, T. Paradigm Change or Old Wine in New Bottles? Debating and Reformulating SDGs-An Experiment. Institute of Social Anthropology; University of Bern: Bern, Switzerland, 2018; Available online: http://www.anthro.unibe.ch/unibe/portal/fak_historisch/dkk/anthro/content/e40416/e96353/ e96354/files747906/SDG_Text_FInal_ger.pdf (accessed on 5 March 2020).

8. Haller, T.; Adams, T.; Gmür, D.; Käser, F.; Lanz, K.; Marfurt, F.; Ryser, S.; Schubiger, E.; Von Sury, A.; Gerber, J.-D. Large-Scale Land Acquisition as Commons Grabbing: A Comparative Analysis of Six African Case Studies. In Global Perspectives on Long Term Community Resource Management; Springer Cham: Berlin/Heidelberg, Germany, 2019; pp. 125-164.

9. Ferguson, J. The Anti-Politics Machine: "Development" and Bureaucratic Power in Lesotho; University of Minnesota Press: Minneapolis, MN, USA, 1994.

10. Ferguson, J. Global Shadows: Africa in the Neoliberal World Order; Duke University Press: Durham, UK; London, UK, 2006.

11. Haller, T. (Ed.) Disputing the Floodplains: Institutional Change and the Politics of Resource Management in African Floodplains; Brill: Leiden, The Netherlands, 2010.

12. Haller, T. Towards a New Institutional Political Ecology. In The Commons in a Glocal World; Haller, T., Breu, T., de Moor, T., Rohr, C., Znoj, H.P., Eds.; Routledge: London, UK, 2019; pp. 90-120.

13. Haller, T. The Different Meanings of Land in the Age of Neoliberalism: Theoretical Reflections on Commons and Resilience Grabbing from a Social Anthropological Perspective. Land 2019, 8, 104. [CrossRef]

14. Toulmin, C. Securing land and property rights in sub-Saharan Africa: The role of local institutions. Land Use Policy 2009, 26, 10-19. [CrossRef]

15. Haller, T. Managing the Commons with Floods: The role of institutions and power relations for water governance and food resilience in African Floodplains. In Water and Food-Africa in a Global Context; Ostegard, T., Ed.; The Nordic African Institute: Uppsala, Sweden, 2016; pp. 369-397.

16. Marfurt, F.; Käser, F.; Lustenberger, S. Local Perceptions and Vertical Perspectives of a Large Scale Land Acquisition Project in Northern Sierra Leone. Homo Oeconomicus 2016, 33, 261-279. [CrossRef]

17. Hall, R.; Edelman, M.; Borras, S.M.; Scoones, I.; White, B.; Wolford, W. Resistance, acquiescence or incorporation? An introduction to land grabbing and political reactions 'from below'. J. Peasant. Stud. 2015, 42, 467-488. [CrossRef]

18. Scott, J.C. Weapons of the Weak. Yale; University Press: New Haven, CT, USA, 1987.

19. Niederberger, T.; Haller, T.; Gambon, H.; Kobi, M.; Wenk, I. (Eds.) The Open Cut: Mining, Transnational Corporations and Local Populations; LIT Verlag: Berlin, Germany; London, UK, 2016.

20. Marfurt, F. Gendered impsacts and coping strategies in the case of a Swiss bioenergy project in Sierra Leone. In The Commons in a Glocal World; Haller, T., Breu, T., de Moor, T., Rohr, C., Znoj, H.P., Eds.; Routledge: London, UK, 2019; pp. 318-335.

21. Haller, T.; Acciaioli, G.; Rist, S. Constitutionality: Conditions for Crafting Local Ownership of Institution-Building Processes. Soc. Nat. Resour. 2015, 29, 68-87. [CrossRef]

22. Haller, T.; Belsky, J.M.; Rist, S. The Constitutionality Approach: Conditions, Opportunities, and Challenges for Bottom-Up Institution Building. Hum. Ecol. 2018, 46, 1-2. [CrossRef] 
23. Ameso, E.A.; Bukachi, S.A.; Olungah, C.O.; Haller, T.; Wandibba, S.; Nangendo, S. Pastoral Resilience among the Maasai Pastoralists of Laikipia County, Kenya. Land 2018, 7, 78. [CrossRef]

24. Hak, S.; McAndrew, J.; Neef, A. Impact of Government Policies and Corporate Land Grabs on Indigenous People's Access to Common Lands and Livelihood Resilience in Northeast Cambodia. Land 2018, 7, 122. [CrossRef]

25. Chabeda-Barthe, J.; Haller, T. Resilience of Traditional Livelihood Approaches Despite Forest Grabbing: Ogiek to the West of Mau Forest, Uasin Gishu County. Land 2018, 7, 140. [CrossRef]

26. Ngutu, M.; Bukachi, S.A.; Olungah, C.O.; Kiteme, B.; Kaeser, F.; Haller, T. The Actors, Rules and Regulations Linked to Export Horticulture Production and Access to Land and Water as Common Pool Resources in Laikipia County, Northwest Mount Kenya. Land 2018, 7, 110. [CrossRef]

27. Augstburger, H.; Käser, F.; Rist, S. Assessing Food Systems and Their Impact on Common Pool Resources and Resilience. Land 2019, 8, 71. [CrossRef]

28. Alvarado, L. Institutional Change on a Conservationist Frontier: Local Responses to a Grabbing Process in the Name of Environmental Protection. Land 2019, 8, 182. [CrossRef]

29. Achiba, G.A. Navigating Contested Winds: Development Visions and Anti-Politics of Wind Energy in Northern Kenya. Land 2019, 8, 7. [CrossRef]

30. Ryser, S. The Anti-Politics Machine of Green Energy Development: The Moroccan Solar Project in Ouarzazate and Its Impact on Gendered Local Communities. Land 2019, 8, 100. [CrossRef]

31. Gmür, D. Not Affected the Same Way: Gendered Outcomes for Commons and Resilience Grabbing by Large-Scale Forest Investors in Tanzania. Land 2020, 9, 122. [CrossRef]

32. Haller, T.; Zingerli, C. (Eds.) Towards Shared Research: Participatory and Integrative Approaches in Researching African Environments; Transcript Verlag: Bielefeld, Germany, 2020; p. 181.

(C) 2020 by the authors. Licensee MDPI, Basel, Switzerland. This article is an open access article distributed under the terms and conditions of the Creative Commons Attribution (CC BY) license (http://creativecommons.org/licenses/by/4.0/). 